\title{
What's an ESL Teacher Good For?
}

Patsy M. Lightbown

\footnotetext{
While ESL teachers often must play many roles, their fundamental task is to help learners progress in their ability to use English. In this paper, the ESL teacher's role as a language teacher is explored and five specific areas of responsibility are elaborated: (1) Providing comprehensible input; (2) Preparing

learners to cope with non-classroom language; (3) Providing references and resource materials and guidance as to their use; (4) Providing focussed instruction in particular areas of language or language use; (5) Providing corrective feedback under certain conditions.
}

In these days of budget cutbacks and job insecurity, the question in the title of this paper may have a familiar-and ominous-ring. On the other hand, the title may lead some teachers to reflect on the many things ESL teachers are good for-besides teaching English. Those who have taught English for academic purposes or specific purposes know that ESL teachers are thought to be good for teaching about physics and engineering. A fairly large number have learned the hard way that, when abroad, Canadian ESL teachers are good for giving expert lectures on the Canadian economy, Canadian literature, Canadian history, and even U.S. foreign policy. In many primary schools, an ESL teacher is good for easing a bewildered immigrant child into the world of school, often being the one person in the school who manages to communicate with the children and their families. In adult education classes for immigrants too, ESL teachers often serve as mediators between newcomers and the Canadian culture.

An anthropologist or ethnographer following some ESL teachers would probably write a description that would sound more like our image of a social worker than of a language instructor. ESL teachers find themselves called on to help their students select proper clothing for the Canadian winter, interpret a letter from an immigration officer, find an apartment in a better neighborhood, get a child registered at school. Even at the university level, the ESL teacher is often an advocate-assisting with visa problems, explaining academic regulations, sorting out misunderstandings about male-female relationships in North American society, or finding a way to tide a student over until money comes from home.

While all these many roles for the ESL teacher are important-and while most people in this profession got into it knowing they were join- 
ing one of the so-called "helping professions"-the focus of this paper is on the teacher's roles and responsibilities with regard to students' language learning.

It seems to be especially important at this point in the history of language teaching methodology and language acquisition research to reflect on what an ESL teacher is good for. A number of current trends may seem to suggest that the teacher's role is diminishing in importance. For example, some research on group work in class suggests that learners may learn best from each other (see Long \& Porter 1985). The increasingly popular use of computers may give the impression that learners learn best from machines which tailor the program of instruction to the individual learner's needs. Research in language acquisition seems to show that the cognitive structures which learners innately possess permit them to bring to the task of language learning the ability to discover the language on their own, following the predetermined paths dictated by a "built in syllabus" (Corder 1967). Some researchersincluding me, I'll confess-have found some evidence that classroom instruction sometimes appears to interfere with successful acquisition rather than contributing to it (Lightbown 1983a, b, 1985a).

In a 1975 article titled "The essential contribution of formal instruction to adult second language learning", Krashen and Seliger start from the premise that, for adult second language learners at least, formal instruction is "good for you"-essential, in fact, as suggested by the title of their paper. In that article, Krashen and Seliger conclude that the two components shared by all teaching methods known to them at that time were discrete point presentation, that is, the presentation to learners of one reasonably well-defined bit of language at a time, and feedback on error, some kind of information about whether what a learner is saying conforms to the rules and patterns of the target language. Much has changed since the publication of that article, and Krashen's current view is that the real value of classroom instruction does not lie in either of these common threads. Its value lies rather in the fact that classrooms are contexts in which learners can have access to language at their level-"comprehensible input," as he says-which is all the learner really needs, as long as his "affective filter" is low and his motivation to learn is high (Krashen 1981, 1985).

Krashen has based this change in his view of the role of formal instruction partly on research and partly on intuition. With regard to the role of discrete point presentation, Krashen refers to the body of research showing a fairly strong tendency for learners who have had a variety of different instructional experiences to acquire certain English grammatical morphemes in a fixed sequence. This suggests that the sequence or order in which learners are exposed to certain aspects of the language will not determine the sequence in which they are 
acquired. The acquisition sequences appear thus not to be dependent on the discrete point presentation. In some research, acquisition sequences even seem to run counter to the order of presentation. With regard to the second characteristic of formal instruction, feedback on error, research in both $\mathrm{L} 1$ and $\mathrm{L} 2$ acquisition suggests that in non-classroom settings, caretakers and interlocutors rarely even react to, much less overtly correct, a learner's grammatical errors, but instead respond to the meaning. And in these settings, learners learn the language quite well-better, some would say, than in instructional settings where teachers have generally taken the responsibility of pointing out learners' errors to them.

Krashen's current hypothesis-far from suggesting that discrete point presentation and feedback on error are required for second language acquisition (SLA)-suggests instead that the necessary and sufficient conditions for language acquisition are fulfilled if the learner can have access to intrinsically interesting and comprehensible input in an environment where he/she is motivated to learn the language and is not inhibited by stress or pressure to perform and where the input includes " $i+1 "-$ target language complexity slightly beyond what the learner has already mastered (Krashen 1982, 1985). Formal instruction which focuses the learner's attention on some particular aspect of language is, in this formulation, only useful for what Krashen now calls language learning, and information thus obtained is useful to the learner only for monitoring his output under circumstances where he cares less about what he is saying than how he is saying it.

In the face of this view, some may wonder whether ESL teachers are good for anything. One might just as well engage a lot of untrained language "monitors" whose low-paying task it would be to simply converse with learners, making an effort to ensure that what they said was comprehensible. As for $\mathrm{i}+1$, remember that Krashen (1982) assures us that "when input is comprehensible, when meaning is successfully negotiated, $i+1$ will be present automatically, in most cases" (p. 68). The footnote to "in most cases" cites the unusual cases where this will not be true-limited discourse contexts such as serving at a gas station or deli counter. With all these conversational partners providing comprehensible input at minimum wage, we could send all the obsolete ESL teachers back to school to get proper training as social workers!

What is an ESL teacher good for? I am convinced that the role of the teacher in contributing to successful second language acquisition has increased in complexity and that teachers have an even greater role to play than in the days when they were essentially drill sergeants, putting students through their error-free exercises and paces as rapidly as possible. What are the teacher's roles and responsibilities? With no pretense of providing an exhaustive list of those roles and responsibilities-even 
if I stick to the role of language teacher and leave aside the social worker functions-I believe the following ones are especially important in light of ongoing research on second language acquisition:

(1) Providing comprehensible input-from the teacher's own speech or from other learners or electronic aids.

(2) Preparing learners, through the selection of appropriate tasks, to cope with the language outside the confines of the classroom.

(3) Providing access to reference and resource materials to answer students' questions on how to say something, what something means, how to spell something or, even, what the rule is for some aspect of English. Students should also be taught-through experiencehow to use such material.

(4) Providing focussed instruction on some areas of recurring difficulty in language or language use. Such areas may be identified through the teacher's own observation or pedagogical intuitions or through familiarity with SLA research, contrastive analysis, or other linguistic descriptions.

(5) Providing negative feedback and correction when learners request it, when an error is persistent and the learner seems not to realize this, or when the teacher knows-from his own experience or familiarity with research-that the particular error is one which is often fossilized by learners with this background.

The case for role (1)-the necessity to provide comprehensible inputis in keeping with current SLA research and theory (see Lightbown $1985 \mathrm{~b}$ for review). Role (2)-preparing learners to cope with out-ofclass contacts with English-involves creating and selecting tasks which engage the learners in real language use and make it necessary for them to develop strategies for coping with what they do not understand or cannot express. Such task-based instruction is crucial for immigrants and others in second language contexts, not only to prepare them to function outside the classroom, but also to equip learners with skills and strategies which will in turn give them access to more comprehensible input in encounters with English speakers outside the classroom. Task-based instruction is also valuable in foreign language situations because it can give learners the tools and motivation to seek further input, e.g. through reading (see Long 1985a, for discussion of taskbased instruction). My focus here will be on the teacher's responsibilities in roles 3,4 , and 5 above: reference sources, focussed instruction, and explicit feedback on errors.

White (in press), has presented a theoretical framework for the hypothesis that comprehensible input may not always be sufficient and that overt explicit grammatical instruction may sometimes be helpful or even necessary for progress to a more advanced stage. She discusses 
several cases of linguistic structures which appear to be analogous, but which are in fact subject to different constraints in a learner's L1 and L2. Such differences are numerous, of course, but among them there is a sub-group for which learners will not be able to find information in the input to tell them what is not possible. Thus they will infer that if structures are comparable in four out of five ways, they must also be comparable in the fifth way as well. White suggests that

for L2 acquisition, it is conceivable that in situations like these, where the learner has carried over an $\mathrm{L} 1$ form which is not obviously disconfirmed by the input from L2, or where the L1 has had other more subtle effects on the way the learner perceived the L2 input, correction or specific, fine-tuned grammar teaching might also be a useful source of input, a means to stimulate change and lead to a different stage in the acquisition process. In other words, the role of correction or grammar teaching would not be merely to improve the monitoring abilities of the learner (emphasis mine).

Even if we take the basic mechanism for progress as "acquisition" rather than "learning" and comprehensible input as the basic raw material required to drive that mechanism, it is not clear why Krashen would reject the possibility that explicit focus on language should not aid that mechanism by making input comprehensible. For example, if you are a learner of German with reasonably well developed metalinguistic skills in your L1, it seems likely that being told early on something about the peculiarities of verbs in German word order would aid your comprehension of German. (Of course, this is an empirical question, one which could usefully be investigated.)

While it is certainly a well-documented fact that formal instruction which starts from a focus on form and grammatical correctness will not, in itself, lead to communicative fluency, it is also increasingly clear that an abundance of comprehensible input will not automatically lead to the correction of grammatical or functional (discourse or sociolinguistic) errors or, put another way, to progress to the next developmental stage (see Higgs \& Clifford 1982, Swain \& Harley 1984). One of the most valuable things about new communicative approaches to L2 teaching is that, in giving learners more opportunities to use real language for real tasks, we are able to get a better fix on their real needs-linguistic and functional: ${ }^{1}$ When you get learners into real tasks of language use, you are able to see much more clearly what they need to work on.

Some evidence that comprehensible input will not always be enough is found in French immersion programs. Students develop high levels of competence in their receptive skills and in their ability to express themselves intelligibly. They do not, however, reach a level of native- 
like proficiency which would be expected from students who at the same age, had had the same number of hours of target language exposure in a "submersion" environment-an environment where the child is surrounded by speakers of the target language. In the immersion classroom, children receive extensive comprehensible input from teachers and peers. Their peers' language, of course, frequently is marked by the same errors or approximations.

Several proposals have been made for improving the accuracy of immersion students' productive language. Some suggest that learners may simply need more comprehensible input and that the solution is to provide more input from native speakers-especially peers. Short of dividing the 150,000 students currently enrolled in immersion across Canada and sending them, in groups of 15, to 10,000 schools in Quebec or francophone areas of Ontario or New Brunswick, it is difficult to say how such peer input could be provided for everyone.

Swain (1985) has proposed that classroom interaction patterns in immersion classes be changed in order to give learners a greater opportunity to produce language-opportunities for what Swain calls "comprehensible output". Swain's observation has been that immersion classes tend to be teacher-centered and teacher-dominated and this gives learners relatively few opportunities to initiate interaction or to engage in the negotiation of meaning. Increasing opportunities for such output could have two benefits: first, giving learners experience in formulating their ideas, that is, practice, but practice at a high level of cognitive functioning where learners are challenged to make the most of their resources, and second, providing learners with opportunities to test their interlanguage hypotheses by discovering what is comprehensible to listeners and what is not.

Swain's proposal has considerable pedagogical appeal in that educational research does suggest that motivation is improved and learners benefit from being challenged to get more involved in their learning. While it seems that such a change in classroom patterns might well enhance motivation and subject matter learning and increase fluency in the language, it is difficult to see how in itself it would result in significant improvements in learners' grammatical or sociolinguistic accuracy in French. That is, the second hypothetical advantage in increasing opportunities for comprehensible output (giving learners opportunities to make adjustments to their interlanguage on the basis of the reactions of listeners whose failure to comprehend non-target forms would trigger instability or uncertainty in the interlanguage) would be harder to achieve. In a context where interlocutors are native speakers, the learners will presumably encounter some difficulty in making their output comprehensible if it does not conform to target lanaguage rules. In the immersion context where learners share the same native language as 
well as many non-target-like interlanguage rules, a speaker's output will be readily comprehensible-even if wrong. In such a context there is neither motivation nor information for the learners to alter their current interlanguage hypothesis. However, there is the possibility that encouraging more student talk will make teachers more aware of the learners' points of difficulty. In research on classroom interaction in immersion, Chaudron (1977) noted that immersion teachers, like parents of young children and friends of L2 learners, focus on meaning and rarely correct errors in the form of learners' language. Such a focus probably creates a positive atmosphere for students to speak French, but there is a need to do something to improve students' accuracy as well.

Harley (1985) is currently engaged in an important study in which immersion teachers are given materials which provide focussed practice on a particular area of French grammar in which students have persistent errors according to a number of error analysis studies.

Although there is no explicit metalinguistic explanation of the grammatical point in question, students engage in a number of activities related specifically to this area of difficulty and also, in line with Swain's comprehensible output hypothesis, have many opportunities to produce the forms being focussed on. This experimental study will answer some questions about one approach to overcoming errors which are produced frequently and consistently by immersion students. Preliminary results suggest that these focussed activities have a measurable positive effect, and this experiment provides suggestions for future research on language-focussed activities within a communicative learning context. For example, studies could investigate the use of such an approach with younger immersion learners before the errors become, it would seem, fossilized. It will also be useful to test other focus-andpractice materials with other grammatical or functional aspects of language which have high error rates.

In some pilot research with students receiving a five-month intensive five hour a day ESL program at the grade 5 level in several Quebec schools, we have been struck by the learners' very impressive fluency in English, accompanied by very limited accuracy in supplying certain inflectional morphemes. Older learners who have had the same total number of hours of instruction in more audio-lingual teaching in a nonintensive program over a period of several years, seem to have more limited vocabulary and ease of communication, but more grammatically accurate speech in performing the same task. The intensive program students have been exposed to a very active program of communicatively-based instruction which gives learners many opportunities to speak as well as to understand English.

Given a choice, most language teachers would probably conclude that 
vocabulary richness and fluency are to be chosen in preference to accuracy-being able to express yourself and to understand others is far more important than getting all your verbs conjugated correctly. But are we, in fact, confronted with a choice?

The answer may very well be yes if our students have little contact with the language outside their ESL classes, have poor native language-especially literacy-skills, began learning as adults, or are motivated principally by a need for basic communication. But what about other learners? We have made great strides toward improving language teaching. Watching students develop fluency in communicative language teaching is an exciting experience that many of us have enjoyed. But if we can find ways of improving accuracy as well as fluency, we should strive toward that dual goal. The fact that we have not yet figured out exactly where accuracy fits into communicative language teaching or exactly what the effects of certain kinds of form-focussed or corrective techniques will be in this context, does not mean that we should abandon the effort.

This brings me to role number (5)-providing negative feedback and correction. The tendency for pendulum swing in language teaching is seen in the view that if correcting everything (as in the audio-lingual methods) does not work, then the obvious thing to do is correct nothing. This reminds me of the study-or rather the interpretation of a studywhich Courtney Cazden carried out in the 1960's (Cazden 1965). She was investigating the role of adults' expansions of children's utterances-those cases where parents hear and understand their child's simple two-word utterance and then expand it to a correct and complete adult sentence, e.g., "baby sock", "Baby's putting on her socks!" or "Mommy up", "Mommy'll pick you up". Cazden's experiment involved children in all-day daycare where there was an exceedingly high ratio of children to adults. She arranged for three groups of two-year old children to be exposed to three different types of adult interaction on a one-to-one basis for short periods of time over several weeks. Each child in one group, the expansion group, spent time in a quiet room with an adult and a few special toys. The adult expanded everything the child said, e.g., "baby car" "Yes, the baby's in the car"; "read book" "Mary is reading the book". Another group, called the modelling group, had the same playroom context but a different linguistic reaction. The adult would react to or extend what the child said, not repeat it or expand the actual words of the child, e.g., "baby car", "Do you think she can drive?"; "read book", "This is the story of the Three Little Pigs". A third group got no special language interaction, just an opportunity to spend some time in a quiet room playing with the toys used by the other groups with the adult present but interacting only minimally at the verbal level. 
After a few weeks, comparative measures seemed to show that those children who had received the modelling treatment had made the most progress in language development with the expansion and control groups lagging behind. Of course this brief summary oversimplifies the study, and there are many questions which might be raised about the validity of the research design. Nevertheless, the findings of this study were widely referred to for years as showing that expansion was not helpful for language acquisition, and that it was more important to talk to a child in an interactive conversational manner than to explicitly expand the child's utterances. This interpretation influenced clinical practice in speech pathology and continued to be widely reported even after other researchers. For example, Nelson, Carskaddon, and Bonvillian (1973) carried out more sophisticated research showing that, under certain circumstances, selective expansion appeared to accelerate a child's development of particular grammatical structures. In some of the studies, the language structures chosen for expansion-or "recasting"were contrasted with related structures where no such expansion was done, thus permitting more powerful inferences regarding the effect of expansion. The point here is that expansion may be seen as a kind of corrective feedback-offering the learner access to the right (or more "grown-up") way of saying something. When Cazden's research showed that expanding everything was no more effective than expanding nothing, a number of people (not Cazden herself) interpreted it as proving that expansion was simply not helpful.

Similarly, with regard to negative feedback, L1 researchers, Brown and Hanlon (1970) observed that the middle class mothers they followed did not tend to correct the form of their two-year old children's utterances, but focussed instead on meaning. This led an astonishingly large number of people to conclude that there is no role for overt correction in child language. Other research in other cultures has shown parents taking considerable responsibility for correcting their children's speech (Schieffelin 1979). If this research had been reported first and been taken as typical of all "normal" child language development, some very different things might have happened in the fields of language teaching! Certainly other evidence suggests that overt correction plays a minimal role in child $\mathrm{L} 1$ acquisition and that children come to have solid native speaker intuitions about complex linguistic structures they have heard very rarely and have surely never been taught or corrected for, but the inference has been drawn that correction has no role in L1 development and that the same is true for second language acquisition for children and adults. Again there is some evidence to show that learners in nonclassroom settings receive little negative feedback in the form of overt correction. But they also tend to get far larger amounts of exposure to the language and also to be in more context-embedded situations than 
are classroom learners. It is also true that studies of correction behaviour in classrooms are alternately discouraging (because learners continue to make the same errors after repeated correction) and hilarious (because the teacher is trying to correct something without really paying attention to what the learner intends to say, thus giving the learner quite inappropriate feedback). Schachter (1983) has pointed out that we need to allow time for correct form to replace errors. Most research has only looked at immediate incorporation of correct form following feedback.

To conclude that providing corrective feedback is never helpful is to go too far. At the very least we need to do far more research on the effects of different kinds of correction, at different points in the learner's interlanguage development, with learners of different ages, etc. In the meantime, research or no research, ESL teachers still have the responsibility-as language teachers-to let learners know within the limits of their overall proficiency when what they're doing does not conform to the target.

I recently interviewed John Fanselow on the subject of teacher training. I kept trying to get him to agree with me that an important objective of teacher training was to ensure that teachers had some theoretical basis for their classroom behaviours-that they not simply do an activity or play a communication game because it took less time to prepare or the students liked it better than something else. But, while he understood what I was pushing him to agree with, Fanselow had a different point of view. In his view, the first crucial problem to confront is that classrooms are settings where there is too great a tendency to do the same thing over and over again: the same types of activity, the same materials, the same procedures. Fanselow has observed that teachers tend to have less variety in classroom activities at the end of the year than at the beginning, and that it takes students longer to carry out these familiar tasks at the end of the year than at the beginning. In Fanselow's view, this suggests stagnation: students are not truly engaged in learning. His recommendation: Do something different-not necessarily better (you don't know that yet)-just something different. As an example, he may say to a teacher, "You've been having students underline all the words in a text that they don't know. Now have them underline the words they do know." Fanselow explains,

In other words, sometimes I'd ask teachers to do the opposite of what they are already doing in the classroom without a rationale. I tell them to do it not because I am an expert in teaching: I tell them to do it so that they can get a clearer picture of what they are doing by contrasting it with what they are ordinarily doing. After they do the alternative practice a few times, they can compare the consequences of both of them and they can begin to see that there are advantages and disadvantages of each, and that neither of these alternatives is the answer, that in fact both of the 
alternatives and even other alternatives are necessary. As soon as the students begin to learn this game of underlining the words they do understand they'll stop thinking, stop using their mind in a different way and get back to stagnation. (Fanselow 1985)

In the end, I had to agree that it is the teacher who must act in this way as a practical investigator. Try something. See what happens. Try something else. This does not mean that students should be confronted with haphazard disorganization from day to day, rather, that they should have a wide variety of contexts for learning-some inevitably more successful than others. In the end, this apparently ad hoc procedure can be supported by pedagogical theory: for example, not all students learn the same way, so variety will give greater opportunities for all students to find something appropriate to their own learning style preferences; furthermore, the change of activity keeps students alert, motivated, and thus more able to benefit from learning opportunities; in addition, there is rarely such a thing as one-trial learning and a variety of activities permits the recycling or spiralling of content without saying to students "You obviously didn't get that so we'd better do it again." Such explorations by teachers may also entice them to look at some research, asking themselves how different types of activities they have actually tried fit in with one or another hypothesis about how languages are learned. This in turn might lead them to consider new things to try in the classroom.

Recently at Concordia we had a guest speaker, a language acquisition researcher who concluded her remarks by saying, as, I maintain, a responsible researcher in this field ought to do, that applications of her research findings to pedagogical practice could not be made directly. For example, she had worked with certain ethnic groups, on certain communicative functions, in a certain research context. In any case, her research had not been conducted in a regular classroom setting nor had her observations-interesting and suggestive though they werebeen investigated in terms of how learners getting one kind of instruction were different-in the short, medium or long run-from students getting another kind of exposure or instruction.

Following the talk, many people came up to speak to the guest researcher and to me. One teacher is an elementary school teacher whom I have frequently observed and consider to be one of the most gifted teachers I have ever seen. She was bubbling with enthusiasm because the talk she had heard-on the linguistic interaction between non-native speakers in group-work-confirmed some of the practices she had used for several years.

Another teacher, a teacher with many years of experience at all levels and ages, most recently with English for academic purposes, also came up. This teacher also has the reputation of being a super teacher-not 
only brilliant at motivating and stimulating her own ESL students, developing outstanding activities and materials for communicative language teaching, but also as a trainer of new teachers and an inspiration to them. Her reaction to the talk was different. It was not that she had not liked it. She had! But she was very impatient with the speaker-and with me because she knows my orientation is similar-for not saying, "And so, on the basis of this research, we can unequivocally recommend group work for second language acquisition and confirm without doubt that error correction will take care of itself." She seemed to be saying, "You are being irresponsible for not making concrete recommendations." I was stunned and not sure how to respond. With hindsight I think my response should have gone something like this: "You know more about the value of group work-and about its limitsthan anybody here! You've honed and refined your group work techniques through experience with hundreds of students, discussion with your colleagues, study of the relevant SLA research literature, analysis of your students' results, followed by more experience. It would be presumptuous of me or any other SLA researcher to say to you: Do this and I promise it will work! We've seen a certain outcome in a certain context. You have to use your judgement about whether it will work for you-or-more precisely-whether you're willing to try it."

There are too many variables which researchers cannot control or abstract from the specific studies they do. The kind of group work which produces spectacular results among university students in Denmark will be resisted by adult immigrants from countries where the teacher is expected to stand up and teach. It may be necessary in the latter setting to put off group work for a while to gain learners' confidence. Metalinguistic or grammatical explanation may prove very effective for highly educated adult learners, but offer nothing of value to children or non-literate adults. Even at the individual level, there are significant learning style differences. Wesche has observed that learners' choices of classes are often appropriate to their learning style and that if learners feel that the teaching style does not suit their needs, they may be resistant to the method, and they may not learn very much (Wesche 1981).

Recommendations about the teacher's role in the classroom can only come from research on the teacher's role in classroom, but with so many uncontrollable variables, we have difficulty proving that what we see is the result of what the teacher does (or has students do), and problems of generalizability are acute. We are just beginning to ask good precise questions, e.g., What happens when we provide focussed teaching on particular forms when the previous instruction has been “communicative", (Harley 1986). What happens when teachers' question 
forms are altered? (Long et al. 1984). How is input made comprehensible? (Long 1985b, Chaudron 1985).

This does not mean that teachers should ignore research in SLA or classroom interaction. On the contrary, they should take opportunities such as conferences and the professional journals to keep themselves up to date. And above all they should be open to the possibility of trying out some new ideas. But nobody is going to come up with generalizable research results that can properly be interpreted as telling teachers exactly what will work in Shanghai and Chicoutimi, in Rabat and Regina, for francophones and russophones, for children and adults, in second language and foreign language contexts, for intensive EAP and one-hour a week drip-feed courses.

Changes in language teaching methods have almost never come about as the result of research in second language acquisition (Lightbown $1985 \mathrm{~b}$ ). The changes have come from language teachers or pedagogical theories or sometimes-from linguistic theories, and until recently, research in SLA has tended to provide explanations for the relative success of one approach over another. This appears to be changing as more and more SLA research is focussed on the classroom, but for as far in the future as I can see it will be the teacher's responsibility to ask: Is this right for me, right for my students, for their language and culture, their age, their learning goals?

What's an ESL teacher good for? With so much responsibility weighing on their shoulders, we must hope ESL teachers are good for at least another hundred years!

\section{NOTES}

${ }^{1}$ This point was emphasized by Michael Canale in his presentation on research and the classroom at the TESL Ontario/TESL Canada meeting regarding work he is currently carrying out with Patrick Allen, Graham Barker and others at OISE.

\section{REFERENCES}

Brown, R. and Hanlon, C. 1970. Derivational complexity and order of acquisition in child speech. In J.R. Hayes (ed.), Cognition and the development of language. New York: Wiley.

Cazden, C. Environmental assistance to the child's acquisition of grammar. Ph.D. dissertation, Harvard University.

Chaudron, C. 1977. Teachers' priorities in correcting learners' errors in French immersion classes. Working Paper on Bilingualism, 12, Toronto: OISE.

Chaudron, C. 1985. A method for examining the input/intake distinction. In S. Gass \& C. Madden (eds.), Input in second language acquisition. Rowley, Mass.: Newbury House.

Corder, S.P. 1967. The significance of learners' errors. IRAL, 5, 161-170. 
Fanselow, J. 1985. An interview with Johı Fanselow (by P.M. Lightbown). SPEAQ-Out, 14 (2) 9-13.

Harley, B. September 1985. Second language proficiency and classroom treatment in early French immersion. Paper presented at the F/PLV/Eurocentre Symposium on Error in Foreign Language Learning, University of London.

Harley, B. and Swain, M. 1984. The interlanguage of immersion students and its implications for second language teaching. In A. Davies, C. Criper, A. Howatt (Eds.), Interlanguage. Edinburgh: University of Edinburgh Press.

Higgs, T.V. and Clifford, R. 1982. The push toward communication. In T.V. Higgs (ed.), Curriculum, competence, and the foreign language teacher: Skokie, IL: National Textbook Company.

Krashen, S. 1981. Second language acquisition and second language learning. Oxford: Pergamon.

Krashen, S. 1985. The input hypothesis: issues and implications. London: Longman.

Krashen, S. and Seliger, H. 1975. The essential contributions of formal instruction in adult second language learning. TESOL Quarterly, 9 (2), 173-183.

Lightbown, P.M. 1983a. Exploring relationships between developmental and instructional sequences in L2 acquisition. In H. Seliger \& M. Long (eds.), Classroom oriented research in second language acquisition. Rowley, Mass.: Newbury House.

Lightbown, P.M. 1983b. Acquiring English L2 in Quebec classrooms. In S. Felix \& $\mathrm{H}$. Wode (eds.), Language development at the crossroads. Tübingen: Gunter Narr Verlag.

Lightbown, P.M. 1985a. Can second language acquisition be altered by instruction? In K. Hyltenstam and M. Pienemann (eds.), Modelling and assessing second language acquisition. Clevedon: Multilingual Matters.

Lightbown, P.M. 1985b. Great expectations: second language acquisition research and classroom teaching. Applied Linguistics, 6 (2), 173-189.

Long, M. 1985a. A role for instruction in second language acquisition. In K. Hyltenstam and M. Pienemann (eds.), Modelling and assessing second language acquisition. Clevedon: Multilingual Matters.

Long, M. 1985b. Input and second language acquisition theory. In S. Gass \& C. Madden (eds.), Input in second language acquisition. Rowley, Mass.: Newbury House.

Long, M., Brock, C., Crookes, G., Deike, C., Potter, L., and Zhang, S. 1984. The effect of teachers' questioning patterns and wait-time on pupil participation in public high school classes in Hawaii for students of limited English proficiency. Center for Second Language Classroom Research, University of Hawaii at Manoa: Technical report, no. 1.

Long, M. and Porter, P. 1985. Group work, interlanguage talk, and second language acquisition. TESOL Quarterly, 19 (2) 207-227.

Nelson, K., Carskaddon, G. and Bonvillian, J.D. 1973. Syntax acquisition: impact of experimental variation in adult verbal interaction with the child. Child Development, 44, 497-504.

Schachter, J. 1983. Nutritional needs of language learners. In M.A. Clarke and J. Handscombe (eds.), On TESOL '82: Pacific perspectives on language learning and teaching. Washington, D.C.: TESOL. 
Schieffelin, B. 1979. How Kaluli children learn what to say, what to do, and how to feel. $\mathrm{PhD}$ dissertation, Columbia University.

Swain, M. 1985. Communicative competence: some roles of comprehensible output in its development. In S. Gass \& C. Madden (eds.), Input in second language acquisition. Rowley, Mass.: Newbury House.

Wesche, M. 1981. Language aptitude measures in streaming, matching students with methods, and diagnosis of learning problems. In K. Diller (ed.), Individual differences and universals in language learning aptitude. Rowley, MA: Newbury.

White, L. (in press) Against comprehensible input: the input hypothesis and the development of L2 competence. Applied Linguistics (to appear in 1987).

\section{THE AUTHOR}

Patsy M. Lightbown is the Director of the TESL Centre at Concordia University in Montreal. Her research, teaching and publications are in the area of first and second language acquisition. She has been particularly interested in the development of English as a second language in French-speaking adolescents whose principal contact with English is in the ESL classroom. 